\title{
Los archivos del mal: ¿un discurso sin autor? \\ Ildefonso Nalda Nájera en el Archiv der KZ- Gedenkstätte Mauthausen
}

\author{
Alfonso Rubio Hernández \\ Departamento de Historia, Facultad de Humanidades, Universidad del Valle. Cali, Colombia | \\ alfonso.rubio@correounivalle.edu.co / https://orcid.org/oooo-0002-5782-5092
}

\section{Resumen}

A partir del significado de "archivo" que encontramos en la Arqueología del saber, de Michel Foucault, y las interpretaciones que de él hace Giorgio Agamben en Lo que queda de Auschwitz, exponemos algunas consideraciones sobre el concepto de autor en los que hemos denominado "archivos del mal", refiriéndonos con esta expresión a los conjuntos documentales producto de situaciones o regímenes propicios a crear escenarios de violencia disímiles. Estos archivos que, generalmente, se originaron en el ejercicio de unas funciones institucionales, forman parte hoy día de los fondos llamados comúnmente "centros de memoria histórica" y son necesarios poner en marcha el ejercicio de los derechos democráticos. La biografía de Ildefonso Nalda Nájera, que murió en el Campo de Concentración de Mauthausen y el Archiv der KZ-Gedenkstätte Mauthausen, que ahora custodia documentos y objetos relacionados con el Campo de Concentración, constituyen el modelo que ha guiado este artículo.

The archives of evil: A speech without an author? Ildefonso Nalda Nájera in Archiv der KZ-Gedenkstätte Mauthausen

\begin{abstract}
Based on the meaning of "archive" found in the L'archéologie du savoir by Michel Foucault and the interpretations that Giorgio Agamben makes of it in Quel che resta diAuschwitz, we present some considerations on the concept of author that we have called "archives of evil". We use this expression to nominate documentary sets resulting from situations or regimes enabling of dissimilar scenarios of violence. These archives were mostly originated in the exercise of institutional functions. Today they are part of the funds of the commonly called "historical memory centers", regulated by the exercise of democratic rights. The biography of Ildefonso Nalda Nájera, who died in the Mauthausen Concentration Camp, and the Archiv der KZ-Gedenkstätte Mauthausen, that nowadays holds documents and objects related to the Concentration Camp, constitute the model that has guided this article.
\end{abstract}

\section{Palabras clave}

Archivos del mal Nalda Nájera, Ildefonso Campo de Concentración de Mauthausen

Archiv der KZ-Gedenkstätte Mauthausen

Centros de Memoria Histórica

\section{Keywords}

Archives of evil Nalda Nájera, Ildefonso Mauthausen Concentration Camp

Archiv der KZ-Gedenkstätte Mauthausen

Historical Memory Centers 


\section{Introducción}

Después de más de medio siglo de conflicto armado en Colombia, a comienzos del año 2014, comenzó a hablarse de la llegada de la "era post-conflicto" como un deseo cercano a convertirse en realidad. El prolongado y sangriento enfrentamiento armado entre el Estado colombiano y uno de los más viejos movimientos guerrilleros del mundo ha producido innumerables hechos violentos: matanzas, desapariciones y desplazamientos forzados de población civil, secuestros, magnicidios, para-ejércitos, extorsiones, usurpación de tierras. Salir de la estructura mental que tales hechos han ido forjando en la sociedad colombiana, sustentada fundamentalmente por dos grandes pilares: la desconfianza y la anulación del otro, exige recorrer, con toda seguridad, un largo camino donde una Gobernabilidad responsable pueda reconstruir la radiografía de un conflicto que se ha entendido a retazos y en el cual, muchos de sus protagonistas, víctimas y victimarios, todavía permanecen hoy en la sombra.

Como en otros países que han padecido regímenes propicios a crear escenarios de violencia disímiles, sean los casos de Alemania y Austria después de la Segunda Guerra Mundial, el caso de España después de su dictadura franquista, o los distintos casos de Sudáfrica, Grecia, Portugal, y los países de América Latina como Argentina, Paraguay, Chile, Guatemala o El Salvador, los archivos documentales colombianos, cualquiera que sea su rango institucional o su adscripción pública o privada, o lo que haya quedado de ellos ahora que en el año 2016 se ha puesto fin a su conflicto, se han convertido en una pieza clave para posibilitar la reconstrucción histórica de los hechos y la justa "reparación de daños" que a instancias de un signo político u otro, de una asociación u otra, cubra un deber ético.

Nos referimos a Colombia porque hablamos desde este país, en el que ahora nos encontramos, y son recientes los acuerdos de paz y el dinamismo que quiere darse al Centro Nacional de la Memoria Histórica y otras instituciones similares que conservan documentación directamente relacionada con el conflicto armado colombiano. Pero, como decimos, este tipo de archivos o centros documentales, que no son objeto de análisis aquí, se encuentran en muchos otros países y particularmente tomaremos aquí el ejemplo del Archiv der KZ-Gedenkstätte Mauthausen ("Archivo del Lugar de la Memoria del Campo de Concentración de Mauthausen") para pensar en sus fondos documentales como un sistema de relaciones interno que en sus orígenes obedece a la voluntad creadora del régimen burocrático nazi.

Estos son los archivos que, utilizando una terminología procedente de la conocida expresión de Hannah Arendt (la "banalidad del mal"), hemos llamado así, "archivos del mal", archivos no deseados, en el imaginario de un "bienestar universal", que sin embargo tienen origen en todo tiempo y lugar y van creciendo, al parecer (pensemos en los enfrentamientos actuales del Próximo Oriente y África), cada vez con mayores impulsos, como si uno de sus principios, el de la génesis documental, estuviese ligado a la autoría de una inevitable fatalidad.

A partir de esta definición y las concepciones del "archivo" que encontramos en la Arqueología del saber, de Michel Foucault, y las interpretaciones que de ella hace Giorgio Agamben en Lo que queda de Auschwitz; y a través de ciertas experiencias biográficas, ajenas y personales, exponemos algunas consideraciones sobre el concepto de autor, referido, son nuestros intereses ahora, a este tipo de archivos, y la necesidad actual de ellos para poner en marcha el ejercicio de los derechos democráticos, sin ser esto último, como decimos, algo en lo que nos detengamos. Conocer las colecciones documentales que custodia el Archiv der KZ-Gedenkstätte Mauthausen, en la ciudad de Viena, donde también se encuentran objetos que pertenecieron a los sobrevivientes del campo de concentración, nos produjo tal sacudida afectiva que nos llevó a interesarnos por este 
tipo de documentos en relación con la autoría que los originó y en relación al "sujeto" que aparece registrado en ellos como marca representativa de su existencia y su devastadora experiencia en una institución destinada al "exterminio"; la experiencia que trasluce el Libro de los muertos (el Totenbuch) de Mauthausen mediante un lacónico enunciado referido al nombre propio y la fecha en que murió Ildefonso Nalda Nájera ${ }^{1}$.

Este, hay que precisar, es en realidad el asunto central del texto, el concepto de autor en el archivo expuesto por Foucault y analizado por Agamben que analizamos en el apartado titulado "El archivo: ¿un discurso sin autor?". Mientras para el primero no es relevante la génesis del archivo, su función autorial, sino la caracterización de los enunciados potenciales que pueden originarse a partir de él; para el segundo sí es necesario responder a las implicaciones éticas de esos enunciados y para ello la noción de "autor" no puede desaparecer del propio ser del archivo. Es desde esta posición de Agamben de la que partimos para hablar de una voluntad creadora que posibilita la existencia del archivo en relación con unos actos derivados del cumplimiento de la ley.

No se trata, por supuesto, de una exposición ligada a un corpus conceptual propio de la archivística o las ciencias de la documentación, ni mucho menos queremos hablar de ciertas instituciones desde los presupuestos de análisis dedicados al estudio de la memoria histórica. El texto trata tangencialmente, prácticamente solo se enumeran, distintos asuntos que pueden ser articulados entre sí, como los que acabamos de mencionar, y otros relacionados con los derechos humanos, con contextos históricos como el nazismo o el genocidio en general, con la violencia latinoamericana, el funcionamiento y los objetivos de los centros de la memoria actuales, etc. ${ }^{2}$. Pero es evidente que el objetivo central aquí no es este, sino, el que acabamos de mencionar, motivado, por otro lado, por una experiencia emocional particular que ha determinado la estructura y el tono de esta reflexión.

El Archiv der KZ-Gedenkstätte Mauthausen nos dio a conocer un determinado registro burocrático denominado ahora el Libro de los muertos, un libro donde aparecía el distintivo nominal de un personaje por nosotros conocido, Ildefonso Nalda Nájera. Su aparición en el archivo es la causa que nos llevó a elaborar este ensayo. Por ello iniciamos un relato desde una posición y situación personales, con las que creemos aumentar las implicaciones de subjetividad que se hacen explícitas en la definición de archivo que exponemos. Por ello también es pertinente describir primero este archivo y hacerlo como un sistema de relaciones entre sus tipologías documentales u objetuales y un sistema de enunciados enlazado a "leyes de posibilidad", algo que se lleva cabo en el primer apartado ("El Archivo del Lugar de la Memoria del Campo de Concentración de Mauthausen. Un sistema de relaciones"); y dar cuenta luego, en el segundo apartado ("Del registro documental a la biografía. Ildefonso Nalda Nájera [Tricio (La Rioja, España), 1876-Mauthausen (Austria), 1941]") de una existencia oculta detrás de ese concreto nombre propio señalado. La presencia mediante la escritura de un nombre propio, relacionada con la imagen de una ausencia que trasluce una determinada experiencia, ofrece la posibilidad de interpretar el archivo como una biografía.

Estas relaciones que establece el archivo y la breve biografía de Nalda Nájera como experiencia dolorosa de un ser humano funcionan como preámbulo y están en íntima relación con lo que se expone en el tercer y, repetimos, central apartado ("El archivo: ¿un discurso sin autor?"). Se muestran previamente como referente situacional que quiere aclarar y al mismo tiempo reforzar, desde una posición subjetiva, el contenido de este tercer apartado, dirigido al hecho de conceder relevancia al quién del archivo, o sea, a la cuestión de su voluntariedad.
1. Agradecemos la colaboración en la elaboración de este texto a María Hörtner, Christian Dürr y Jesús Vicente Aguirre.

2. Una amplia relación de bibliografía, legislación, fuentes diversas y recursos electrónicos, relacionada con estos y otros asuntos similares puede verse en el texto de Ramón Alberch Fugueras titulado Archivos $y$ derechos humanos (2008). 
El apartado final ("Hacia un relato del nunca más"), a modo de consideraciones finales solo es una constatación de la labor que han experimentado los llamados centros o archivos de la memoria en relación al caso que se expone, la de dar salida a breves reconstrucciones de vida dentro de lo que actualmente se está denominando, así lo expone Leonor Arfuch, "espacios biográficos", como una función de reparación social, tal y como lo está haciendo el Archiv der KZ-Gedenkstätte Mauthausen.

\section{El Archivo del Lugar de la Memoria del Campo de Concentración de Mauthausen. Un sistema de relaciones}

En el mes de septiembre del año 2011 visitamos desde La Rioja (España) la ciudad de Viena con la idea de disfrutar de nuestros últimos siete días del descanso estival, rígidamente contabilizado, que aquel año nos impusimos, pues las obligaciones con las que teníamos que cumplir a la universidad colombina que nos había concedido una comisión académica, no nos permitieron ningún tipo de relajamiento. Nuestra querida amiga María Hörtner tuvo la amabilidad de acogernos en su domicilio de Währinger Gürtel, en la capital austriaca. En la medida de lo que le fue posible, ella fue nuestra guía durante una corta, pero intensa estancia en una ciudad europea que verdaderamente nos tranquilizaba.

Al quinto día, agotados de recorrer jardines, plazas y museos, había que cambiar de actividad para recuperar el ánimo de nuestras piernas y nuestros ojos. María nos propuso entonces visitar el archivo donde trabajaba. Fue una sorpresa saber que trabajaba exactamente en un archivo, pues en los escasos momentos en que hablábamos de nuestro desempeño laboral, ella siempre se refería a la Administración del Gobierno austriaco de manera inconcreta. En esos momentos, un hecho que, recíprocamente, recibió de igual manera, sorpresivamente, le hicimos saber que nuestra vida laboral, desde que esta se inició, contaba con diez años de trabajo ininterrumpido en distintos archivos históricos españoles.

La propuesta se presentaba interesante y tal coincidencia nos predisponía a pasar un día feliz, pues realmente tampoco sabíamos de qué tipo de archivo de trataba. Era la mañana del día 6 y allí estábamos, en un enorme edificio administrativo, de largos, robustos y estrechos pasillos y amplias medidas de seguridad, que albergaba el Archiv der KZ-Gedenkstätte Mauthausen. Antes de pasar a visitar el archivo, María había concertado una entrevista con su director, Christian Dürr, puesto que después de una reestructuración administrativa, ahora se denomina "curador". Por medio de sus explicaciones y respondiendo con amabilidad a todas nuestras curiosas preguntas, siempre en el perfecto castellano que empleaba, pudimos hacernos una idea general del significado y el alcance del archivo.

El llamado Archiv der KZ-Gedenkstätte Mauthausen es entendido como un centro de documentación científico que se inscribe dentro del marco de trabajo sobre la recuperación de la memoria y la concienciación que viene desarrollando el KZ Gedenkstätte Mauthausen (Memorial del campo de concentración de Mauthausen). El archivo hace parte de la totalidad de este centro que se ha denominado "Memorial" y actualmente es una institución autónoma y nacional de derecho público (Bundesanstalt öffentlichen Rechts) financiada por el Ministerio del Interior. Aunque es financiado por una entidad estatal, no puede ser considerado como un archivo público en tal sentido debido tanto a la clase de material administrado que contiene, como al hecho de que no está sujeto directamente a las leyes archivísticas de Austria. Custodia toda clase de fuentes, mayoritariamente copias, relacionadas con la historia del antiguo campo de concentración y del "Memorial". Se constituye más bien como un centro de documentación o una colección de museo. Como el archivo hace parte de la 
KZ-Gedenkstätte Mauthausen, las leyes relevantes que le atañen son las de Öffentlichen Denkmals Mauthausen (Monumento Público Mauthausen) y la Kriegsgräberfürsorgegesetz (Ley de Protección de Fosas de Guerra), ambas del 7 de julio de1948, con las cuales el Ministerio del Interior obtuvo la competencia y la responsabilidad del cuidado y la protección de las fosas de guerra y de los monumentos de guerra de la Segunda Guerra Mundial. Igualmente le incumbe la Declaración de Monumento Nacional del antiguo campo de concentración de Mauthausen del año 1949.

La colección del archivo se fundamentó en la creación de un museo dentro de la $K Z$-Gedenkstätte Mauthausen en los años sesenta. En ese entonces, el antiguo preso del campo de concentración y jefe de policía, Hans Maršálek, fue encargado por parte del Ministerio del diseño de una exposición permanente sobre la historia del campo de concentración Mauthausen y sus subcampos. Maršálek pudo aprovechar sus contactos con antiguos presos, asociaciones de sobrevivientes y archivos estatales fuera de Austria para recolectar las primeras fuentes sobre la historia del campo de concentración y sus presos. De este modo, paralelamente a la exposición, se pudo compilar una colección de documentos que fue guardada en el Ministerio del Interior de Viena. Hasta los años noventa este inventario originario solo fue engrosado puntualmente y a pequeña escala.

En relación con diferentes proyectos científicos y ante la extensión de las actividades de la KZ-Gedenkstätte Mauthausen, apenas a mediados de los años noventa el inventario del archivo se fue ampliando sucesivamente con inventarios completos o parciales de otros archivos, y con fuentes singulares, en la mayoría de los casos en copia. Desde su creación en los años sesenta el archivo se fue ubicando en diferentes salas del Ministerio del Interior y actualmente se halla en el edificio de Argentinierstraße 13, Top 103+104, 1040 Wien.

En sus comienzos la colección del archivo primordialmente era utilizada para la ya mencionada exposición permanente, que fue inaugurada en 1970 en la KZ-Gedenkstätte. Con el paso del tiempo, otra función se fue convirtiendo en la más importante, relacionada también con otra competencia del Ministerio del Interior, el Personenstandsrecht: a base de las fuentes conservadas del campo de concentración, como ejemplo listas de nombres, libros de registro, obituarios, etc., fue posible dar razón sobre el paradero de personas desaparecidas y entregar certificaciones oficiales de internación a personas sobrevivientes.

A partir de los años noventa, las actividades centrales del archivo, además de las ya nombradas, se enfocaron más hacia el trabajo histórico de concienciación y al acompañamiento científico de recuperación de la memoria, aunque debido a las leyes de restitución para antiguos trabajadores forzados y esclavos, en la Alemania y Austria de la década del 2000 comenzaron a aumentar las demandas y solicitudes de búsqueda de personas. Como otro enfoque central, actualmente se está interviniendo en la edición de publicaciones científicas, en la cooperación a la investigación y en la realización de proyectos histórico-científicos de iniciativa propia.

El archivo sigue trabajando como lugar de información para sobrevivientes y sus allegados acerca del paradero de personas y certificaciones de internación, pero en los últimos diez a quince años sus funciones han estado más dirigidas a servir a investigadores e interesados en la historia del campo de concentración Mauthausen, al desarrollo de exposiciones y a la organización de eventos públicos como conferencias, charlas, congresos o jornadas.

En cuanto a las colecciones documentales que el archivo conserva, las más importantes son las siguientes: 
1. Colección de documentos: documentos de la antigua administración del campo de concentración (listas de nombres, registros de entrada, fichas de presos, etc.), documentos de justicia post-guerra (juicios contra los victimarios), documentos de sobrevivientes y sus parientes (cartas dentro del campo de concentración, correspondencia antes y después de la guerra), documentos de la administración del lugar de la memoria del campo de concentración Mauthausen (Ministerio del Interior, asociaciones de sobrevivientes, etc.)

2. Colección de fotografías: fotografías del campo de concentración, fotografías post-guerra.

3. Colección de entrevistas: entrevistas audiovisuales con sobrevivientes del campo de concentración, con vecinos/pobladores de la región, y victimarios.

4. Biblioteca y hemeroteca: bibliografía y revistas acerca de la historia del campo de concentración y sus subcampos, de persecución, deportación y exterminio durante del régimen nazi en general; del nacionalsocialismo en Austria, de cultura sobre reconstrucción de memoria y política de conmemoración después de 1945 .

5. Colección de artefactos: objetos originales del campo de concentración, objetos originales pertenecientes a sobrevivientes, hallazgos arqueológicos y objetos de postguerra del "lugar de la memoria".

En relación con la historia de los presos españoles, esta, en comparación a la historia de otros presos de otras nacionalidades, está desproporcionalmente bien documentada dentro de la colección general del archivo, pues los presos españoles que sobrevivieron al terrible primer año de su detención, supieron organizarse entre ellos y también pudieron obtener cargos importantes dentro de la jerarquía de presos del campo de concentración. Los españoles que trabajaron en una sección de la Gestapo ("erkennungsdienstliche Abteilung") en el campo de concentración, pudieron sacar fotografías a escondidas y guardarlas hasta el fin de guerra fuera del campo de concentración, como hizo el conocido fotógrafo Francisco Boix. Esta es la razón por la cual hasta hoy en día se pudo conservar una gran cantidad de fotografías oficiales de la SS del campo de Mauthausen.

Además, después de la guerra, muchos españoles, sobre todo en Francia, siguieron sus actividades en distintas organizaciones, coleccionando en sus propios archivos material de interés y parte de esas colecciones hoy figuran en el Archivo del Lugar de la Memoria del Campo de Concentración Mauthausen. Por otro lado, en la Biblioteca del archivo se encuentran las obras españolas y catalanas más importantes sobre la deportación de los españoles republicanos. En los últimos diez años las solicitudes de la tercera y cuarta generación de los antiguos prisioneros españoles también es desproporcionalmente alta en relación al total de solicitudes que el archivo recibe.

Expedientes, registros administrativos, libros, revistas, objetos diversos, seres de distinta corporeidad conviviendo sin problemas bajo un mismo ecosistema, bajo una misma casa llamada "archivo", invitan a desterrar esos planteamientos epistemológicos cerrados y estancos que limitan el campo de interacción entre las disciplinas de la Archivística, la Museología y la Bibliotecología. Una convivencia que debería llevarnos, más bien, a meditar acerca de las íntimas relaciones que existen entre sus prácticas. Elementos físicamente distintos pero enlazados por su trascendencia dentro de un contexto axiológico, pues sus valores representan un complejo conjunto orgánico que incluye lo material, lo cognitivo y lo intelectual (Parada, 2012: 51-52).

Registros de entrada de prisioneros a los campos de Mauthausen y de Gusen, y registros de aniquilados que habían sido confeccionados por quienes de una manera u otra habían participado en el aparato burocrático de la "solución final"; fotografías en blanco y negro cuyos escenarios y personajes, pensábamos, podrían introducirnos en la zona gris de la que habla Primo Levi, la zona donde las víctimas se convierten 
en verdugos y los verdugos en víctimas; entrevistas a sobrevivientes y victimarios que vivieron una determinada realidad y fueron, por tanto, testigos de sus acontecimientos; bibliografía que recoge el enunciado de los testimonios gráficos y orales bajo la mirada del historiador; artefactos y hallazgos arqueológicos que me permitirían recrear escenas cotidianas de vida carcelaria. Una sustanciosa variedad de objetos y tipologías documentales cuyos enunciados textuales, en su forma y en su contenido, nos permitían adjetivar al archivo como un singular conjunto de fuentes informativas que posibilita la reconstrucción arqueológica de algo que en principio no podía catalogar de histórico, pues se nos hacía impensable una realidad tan abrumadora.

Acabadas las explicaciones de Christian Dürr, que casi en su totalidad parecieron darse a manera de reportaje periodístico, él mismo nos mostró una pequeña muestra de cada una de esas tipologías documentales y por último nos llevó al depósito que, con rígidas medidas de seguridad, custodia los llamados "artefactos". Entre los objetos que nos deslumbraron, allí estaban el cepillo de dientes deteriorado y la cantimplora metálica, deformada y rayada, que habían pertenecido a alguno de los prisioneros; los dibujos o ilustraciones que los deportados hicieron recreando el sistema circular duchas de agua fría; y la máquina de escribir con que se registraba, primero la entrada al campo de concentración y luego la muerte de los prisioneros.

Como otras veces habíamos experimentado ante un manuscrito histórico, la sensación de realidad nos atrapó:

Así nace la sensación ingenua, pero profunda, de rasgar un velo, de atravesar la opacidad del saber y de acceder, como tras un largo viaje incierto, a lo esencial de los seres y de las cosas. El archivo actúa como un despojamiento; plegados en algunas líneas aparecen, no solamente lo inaccesible, sino lo vivo. Trozos de verdad actualmente vencidos aparecen ente la vista: cegadores de nitidez y de credibilidad (Farge, 1991: 11-12).

Pero más allá de esas sensaciones conocidas ante un viejo manuscrito, aquí, los artefactos, la máquina a través de la cual se fijaban caracteres alfabéticos que daban cuenta de hechos concretos, y los objetos que un día fueron utilizados por quienes murieron o sobrevivieron padeciendo infames condiciones de vida, nos decían que nada de lo ocurrido en cualquier tiempo y lugar admite comparación con lo que ahora estaba pasando por nuestra imaginación: "unos hechos tan reales que, en comparación con ellos, nada es igual de verdadero; una realidad tal que excede necesariamente sus elementos factuales". Esta es la aporía de los campos de concentración nazis, esta es la aporía, dice Agamben (2005: 9) refiriéndose a Auschwitz, "del conocimiento histórico: la no coincidencia entre hechos y verdad, entre comprobación y comprensión".

En el archivo, casi como los objetos y artefactos que acabábamos de ver, también el puro registro nominal tras el cual se supone toda una vida, se nos representaba como un "objeto sintáctico", un objeto, esta vez, que había recibido directa y plenamente la acción verbal de ser atrapado y aniquilado, la acción verbal transferida mediante una orden militar (escrita u oral) tras la cual también se adivina otra existencia, la de un sujeto concreto. A través de textos escritos y objetos, de apariciones nominales y voluntades creadoras, personales o institucionales, el archivo se constituye como un sistema de relaciones sintácticas (la manera en que se relacionan entre sí los documentos, lo dicho, lo escrito) y semánticas (la manera en que los documentos adquieren significado o son interpretados en relación a una realidad, sus representaciones). Ambas operan dentro y fuera de él. Dentro del archivo existen manifiestas y potenciales relaciones: la máquina de escribir registró al entrar en el campo de concentración a JGP con el número de matrícula 10890, es el mismo número que vemos en los ropajes rayados del preso, de pie, en cuerpo entero y mostrando su rostro, que aparece en una de las 
fotografías que contiene la carpeta clasificada con el año de 1941, y son las mismas iniciales (JGP) que, posiblemente con un canto afilado, se grabaron en una de las cantimploras que custodia el Archiv der KZ-Gedenkstätte Mauthausen; es también el mismo número de matrícula (10890) que más tarde quedó registrado en el llamado Libro de los muertos.

Este solo es un ejemplo de las muchas y evidentes relaciones que se dan en el interior del archivo, relaciones que mantienen en potencia muchas otras y que permanecen ocultas. Solo la intervención de quien sepa descubrir las relaciones sintácticas y semánticas inherentes al archivo, podrá multiplicarlas con nuevos objetivos, con nuevos textos y nuevos personajes, con complejas o sólidas interpretaciones, con nuevas o consabidas orientaciones disciplinares. En cualquier caso, las formas y modalidades con que se apropian y se muestran los discursos emanados del archivo son, indudablemente, un indicio donde se entreteje una gran diversidad de significados y representaciones como una dialéctica entre objetos y textos y su descubridor lector-intérprete.

En el afuera del archivo ha habido un antes de él, un antes de su creación, y hay una contemporaneidad. Mientras él exista siempre habrá una contemporaneidad. Un antes que presupone la voluntad administrativa de formular documentos escritos y acumularlos, y la voluntad de recoger y conservar objetos y piezas arqueológicas que tienen relación con la institución que da origen al documento burocrático; y una contemporaneidad que según el uso que se haga del archivo, dirigirá las miradas de su contenido hacia unos intereses u otros de nuestro tiempo. Sólo si el archivo desaparece, así como desaparecieron las existencias de muchos de los prisioneros de Mauthausen, puede haber un después de él. Pero los procedimientos de preservación y conservación, los mismos que siguen prolongando la vida de las tabletas de arcilla de Asurbanipal, los papiros de las bibliotecas de los egipcios, a las que llamaban "Casas de la vida", o los rollos griegos de las Biblioteca de Alejandría, imposibilitan la muerte natural del archivo, y lo colocan, desde su pasado original, en instancias de futuro: el pasado y el futuro se proyectan en nuestro presente para forman así múltiples y variadas representaciones del archivo como "ente" y de los discursos que se originan a través de él.

Para Foucault el archivo no es la institución que registra y conserva los discursos cuya memoria da cuenta de un pasado y de una concreta identidad, no es la suma de todos los textos que una sociedad o cultura custodia. No es solo lo que salvaguarda el acontecimiento del enunciado. Inscribe al archivo en el "sistema de la discursividad". Si hay cosas dichas, estas no han surgido solamente por las leyes del pensamiento o el juego de las circunstancias, no debemos preguntar su razón a las propias cosas dichas o a los hombres que las han dicho, sino al "sistema de la discursividad", al nivel discursivo caracterizado por un cruce de relaciones donde se originan las posibilidades y las imposibilidades enunciativas: "el archivo es [...] la ley de lo que puede ser dicho, el sistema que rige la aparición de los enunciados como acontecimientos singulares". Partiendo de un "a priori histórico" (una historia que está dada, la de las cosas efectivamente dichas) que sería no la condición de validez, sino la condición de realidad de los enunciados, en el conjunto de las prácticas discursivas hay "sistemas que instauran los enunciados como acontecimientos (con sus condiciones y su dominio de aparición) y cosas (comportando su posibilidad y su campo de utilización)". A esos sistemas de enunciados (acontecimientos y cosas) es a lo que Foucault propone llamar archivo, a la dimensión que corresponde al plano de la enunciación, al "sistema general de la formación y de la transformación de los enunciados" (Foucault, 1983: 218-221).

Para explicar esta definición de archivo, Agamben parte de la teoría de la enunciación propuesta por Émile Benveniste en su estudio sobre "Semiología de la lengua", de una 
"semántica del discurso" y de un "análisis translingüístico de los textos" mediante una metasemántica construida sobre la "semántica de la enunciación". La formulación de sus presupuestos lleva a deducir que la enunciación no se refiere al texto del enunciado, sino al hecho de que tenga lugar: "el aislamiento de la esfera de la enunciación permite distinguir por primera vez, en un enunciado, lo dicho del hecho de que este tenga lugar". La novedad de La arqueología del saber (1969) es la de formular un método de investigación fundado en una teoría de los enunciados. La Arqueología toma como objeto de análisis no las frases ni las proposiciones del análisis lingüístico, "sino los enunciados, no el texto del discurso sino el hecho de que este tenga lugar". La enunciación no se refiere al texto, sino al puro acontecimiento de lenguaje, no a lo dicho sino a lo decible que queda no dicho en ello (Agamben, 2005: 143-145).

El enunciado, dice Foucault, no es una estructura, sino una "función de existencia". El enunciado "está ligado a un referencial que no está construido por cosas, por hechos, por realidades, o por seres, sino por leyes de posibilidad, reglas de existencia para los objetos que en él se encuentran nombrados, designados o descritos, para las relaciones que en él se encuentran afirmadas o negadas" (Foucault, 1983: 145 y 152). La arqueología parte por tanto del hecho de que los discursos tengan lugar, es decir, del "afuera del lenguaje, del hecho bruto de su existencia". El archivo, constituido por un sistema de enunciados ligados a "leyes de posibilidad", a "reglas de existencia" que definen los acontecimientos del discurso, se sitúa entre la "lengua" como sistema de construcción de las frases posibles, y el "corpus" que recoge las palabras pronunciadas o escritas, lo ya dicho: "el archivo es lo no dicho o lo decible que está inscrito en todo lo dicho por el simple hecho de haber sido enunciado". Desde ese "a priori histórico", la pretensión de la arqueología es interrogar a lo ya dicho en el nivel de su existencia como sistema de relaciones entre lo dicho y lo no dicho (Agamben, 2005: 146 y 151).

El archivo aparece como una entidad que con infinita capacidad de acumulación contiene discursos ya efectuados, formas objetuales, grafismos alfabéticos, amontonados bajo el polvo inmemorial que "duermen un sueño hacia el cual no han cesado de deslizarse desde que fueron olvidados y su efecto visible se perdió en el tiempo". Documentos que remiten a la instancia de su enunciación cuyo desciframiento puede liberar significaciones, pensamientos deseos, fantasmas. La lectura que descifra las marcas del discurso pasado puede encontrar algo de su vivacidad perdida, pero para Foucault lo que corresponde al "análisis enunciativo" no es despertar a los textos de su sueño eterno para encontrar las marcas legibles de su superficie, la razón de su nacimiento. De lo que se trata, dice, "es de seguirlos a lo largo de su sueño, o más bien de recoger los temas anejos del sueño, del olvido, del origen perdido, y buscar qué modo de existencia puede caracterizar a los enunciados independientemente de su enunciación" (Foucault, 1983: 208-209).

Documentos escritos, fotografías, entrevistas a sobrevivientes, objetos que, tal vez por su materialidad específica para ser usados con una determinada finalidad, nos trasladaron a una realidad más real que la de los propios objetos, una realidad donde estos funcionaban como enunciados que un día convivieron al lado de existencias humanas que habitaron la experiencia del Campo de Concentración de Mauthausen.

Mientras Christian Dürr explicaba al detalle el contenido y el significado de los documentos que nos mostraba, recordamos entonces que habíamos llegado a Viena un 1 de septiembre, justamente el mismo día que en 1939 Alemania invade Polonia y comienza así la Segunda Guerra Mundial. El número de muertes en combate o el número de víctimas en los numerosos campos de concentración nazis que se establecieron, no tenía importancia en aquellos momentos, pero desde que acabó la Guerra Civil española en el mismo año de 1939 y hasta el fin de la Guerra Mundial en 1945, 
más de siete mil republicanos españoles pasaron por Mauthausen y sus subcampos, y aproximadamente cinco mil murieron en ellos.

El estado de ánimo de satisfacción con el que recorrimos el archivo, se envolvió, al menos en nuestro caso, de una emoción que momentáneamente paralizó nuestros sentidos, pues tres nombres, bajo los cuales se adivinan existencias reales, golpearon repentinamente nuestra cabeza; los nombres de Juan Calvo Garijo, Teodoro Pérez Sáenz e Ildefonso Nalda Nájera. Jesús Vicente Aguirre los registra en Aquínunca pasó nada. La Rioja, 1936 (2008), un texto que, en palabras del propio Aguirre, "rescata del ominoso olvido los rostros, los nombres y apellidos, las señas de identidad personal, familiar y política" de quienes entonces eran habitantes de la Provincia española de Logroño (actual Comunidad Autónoma de La Rioja) y fueron asesinados, encarcelados o represaliados durante la guerra y la posterior dictadura franquista. Juan Calvo era natural de la población de Cervera del Río Alhama; Teodoro Pérez, de Calahorra; e Ildefonso Nalda, de Tricio. Las tres poblaciones pertenecen a La Rioja y, tal vez por la cercanía de Cervera y Calahorra a nuestro pueblo natal de Arnedo; $y$, con seguridad, por el recorrido biográfico que ya conocíamos de Ildefonso Nalda, en esos instantes solo recordamos a ellos, tres concretas existencias que padecieron la realidad de Mauthausen.

Desde el año 2005, en el que Carlos Muntión Hernáez (2005: 10-26) dio a conocer algunos datos biográficos de Ildefonso Nalda Nájera, sabíamos de la persecución política que el régimen franquista le hizo y el desenlace de su vida en el Campo de Concentración de Gusen. Se lo hicimos saber a Christian Dürr y él nos habló del Totenbuch (Libro de los muertos) de Mauthausen. Inmediatamente nos dirigimos hacia el computador que se situaba en el centro de la sala de consulta y, después de unos pocos minutos de búsqueda, allí estaba, era el registro escaneado del Totenbuch donde aparecía escrito, alineado de manera vertical junto a otros, el nombre de Ildefonso Nalda Nájera.

Después de visitar la "cámara sellada" de artefactos y ver el nombre propio de alguien que había nacido en la misma "comunidad" española que la nuestra, estampado en los registros documentales que un día formaron parte de la realidad de los campos de concentración nazis, al deslumbramiento emocional que esto nos produjo se le sumó la posibilidad de visitar al día siguiente el propio Campo de Concentración de Mauthausen. Así lo acordé con los archivistas que serían nuestros guías, pero horas antes de la cita, urgentes compromisos familiares nos lo impidieron. Decidimos entonces acordar otra cita. En el barrio turco de Viena nos encontramos con el padre de María, Werner. Fue él quien alivió el estado de decepción que todavía cargábamos por no haber podido desplazarnos a Mauthausen, a 170 kilómetros de la capital austriaca. Werner murió en junio de 2015 y este texto es un homenaje a él. Era un alegre tirolés de 68 años de edad entonces y nos dijo que sus temores emocionales siempre le impidieron visitar los campos de concentración. En aquel entonces no entendíamos sus palabras y, por el contrario, nuestros deseos por conocerlos aumentaron. Pero al poco tiempo tuvimos que regresar a La Rioja, sin cita ni visita alguna para poder descubrir los escondrijos del Campo de Concentración de Mauthausen.

\section{Del registro documental a la biografía. Ildefonso Nalda Nájera [Tricio (La Rioja, España), 1876-Mauthausen (Austria), 1941]}

Entre los registros del Totenbuch se encuentran los españoles que fueron internados en el campo de exterminio nazi de Mauthausen desde el 6 de agosto de 1940 al 20 de diciembre de 1941. Contiene las fichas con el nombre, lugar de nacimiento, número, fecha y campo de muerte del prisionero. Las listas fueron recuperadas por los supervivientes y actualmente se custodian en la Amicale des Deportés et Familles de Disparus 
de Mauthausen, una organización francesa, con sede en Barcelona, cuyo objetivo es el de perpetuar la memoria del campo de concentración de Mauthausen.

Desde que regresamos a La Rioja, el nombre de Ildefonso, junto al distintivo de sus apellidos (Nalda Nájera), aparecidos en el Archiv der KZ-Gedenkstätte Mauthausen, resonaban en nuestra conciencia con una especie de temblor emocional. La resurrección intacta de su pasado es imposible, pero él, surgido de un manuscrito de archivo se parecía a un requerimiento. Estaba pidiendo ser correspondido. La sensación presencial, de no ser una sombra chinesca, de poder entablar un diálogo con él, nos atrapó:

La emoción no necesariamente genera contemplación, ni tampoco oblación, asimismo, es el ensañamiento empleado en comprender la violencia y la debilidad de las cosas. La mediocridad y lo inaudito de las situaciones; es también la confrontación con lo insólito al mismo tiempo que una manera de dejarse conmover por lo que ya se conoce [...] Trastorna porque asombra: la sorpresa o el terror, el asco o el miedo hacen que uno habite fuera de sí mismo. En ocasiones el archivo, al restituir personajes extraños, remueve nuestras costumbres y la emoción que se aferra a su descubrimiento toma caminos inciertos, incitando a una parte desconocida de nosotros mismos a salir lejos del enternecimiento tan descrito y prohibido. La emoción es accionante (Farge, 1994: 10).

Pero la emoción de este tipo de descubrimientos también embarga. Tiempo después, ante estas palabras de Farge, los relatos de Primo Levi y otros muchos testimonios de supervivientes de los campos de concentración, comprendimos lo que en Viena nos dijo Werner. Tal vez, nuestro interés por la existencia escondida detrás de ese nombre era una manera de sustraernos a una impresión inquietante que emanaba del archivo; como una presencia que nos rodeaba, sustraernos a ese temor por lo oculto e ignoto. Tal vez, tan solo fuese una necesidad físico-química de engordar la estela de curiosidad morbosa que todavía consigue transmitir la muerte estampada en un manuscrito.

La muerte en la historia se presenta planteando una división temporal entre pasado y presente. Sitúa así al archivo en el lugar donde se acumulan las ausencias, no tanto para negar su pérdida, sino para consolarse con ella. Cuando no hay eliminación, evaporización completa del registro documental, cuya función se convierte en ser huella de la supresión de lo vivo, de quien estuvo ahí, hay conservación para el consuelo de quien cuida y alimenta el recuerdo. La lectura del archivo, cuando opera sobre la escritura cotidiana de los silenciados, se asemeja a una aparición fantasmal en el espacio público, porque hace parte de lo efímero, de lo transitorio. Pero no por ello es menos sustancial que cuando opera sobre el ejercicio continuo que fija la escritura ostentosa del poder. Captar lo que hay detrás de un instante requiere revisar los lugares donde hemos estado, limpiar las telarañas que impone la rutina o la costumbre para ver, en esos mismos lugares, lo que antes no veíamos.

A iniciativa del KZ Gedenkstätte Mauthausen y transcurridos unos años, pudimos colaborar en la realización del libro titulado Memorial Book for the Dead of the Mauthausen Concentration Camp. Se publicó en el año 2016 y se presenta como una obra que conmemora a los "muertos del Campo de Concentración" dentro de las obligaciones y funciones de dicho centro y dentro de la responsabilidad social y el deber común. Es una obra colectiva en la que se dan cita más de trescientos registros de breves biografías y entre ellas, sintéticamente, aparece la de Ildefonso Nalda. Antes de que un procedimiento burocrático registrase su muerte en el campo de concentración nazi de Mauthausen, Carlos Muntión Hernáez describe pormenorizadamente las circunstancias por las que tiene que huir de España. A partir de ahí, guiados constantemente por el apoyo de esta descripción, intentamos contextualizar algunos de los 
hechos que Muntión Hernáez da a conocer y para ello elaboramos el texto del cual se tomó la síntesis biográfica que, decimos, hace parte del libro citado; un texto que ahora mostramos completo recorriendo la fría estructura de los hechos que en él se relacionan.

Ildefonso Nalda Nájera nació en 1876 en Tricio, una población de la Provincia española de Logroño que en el año de 1936 contaba con 700 habitantes aproximadamente. En ese mismo año del 36, ya con 60 años de edad, seguía ejercitándose como agricultor, estaba casado con Felisa Pérez-Caballero, tenían siete hijos y su ideología política lo acercaba al partido de Izquierda Republicana.

Cinco meses antes del comienzo de la Guerra Civil española, los días 16 y 23 de febrero de 1936, se celebraron en España las terceras Elecciones Generales (y últimas) de su Segunda República. Los comicios dieron el triunfo a la coalición de izquierdas denominada Frente Popular, que entre otras formaciones políticas agrupaba las del Partido Socialista Obrero Español, Izquierda Republicana, Unión Republicana, Esquerra Republicana de Catalunya, Partido Comunista Español, Acción Catalana, Partido Sindicalista y Partido Obrero de Unificación Marxista.

En la Provincia de Logroño, las elecciones otorgaron tres escaños de diputados a las derechas de la CEDA y uno al Frente Popular, el de Amós Salvador Sáenz Carreras, de Izquierda Republicana. En el pueblo de Tricio de la misma Provincia de Logroño, 262 votos fueron para la CEDA, 60 para la candidatura Católico-Monárquica y 45 para el Frente Popular. El clima de tensión política que se vivía días antes de la Guerra, provoca sucesos de acoso (pedreas, gritos, matanza de animales domésticos, intentos de incendio de la casa familiar) contra la familia Nalda, y el 23 de abril la Junta del Censo Electoral proclamaba a Ildefonso candidato a compromisario para la elección de Presidente de la República. Las elecciones a compromisarios tuvieron lugar el 26 de abril y el boicot de las derechas produjo una abstención del $75 \%$ en Tricio. Ildefonso Nalda obtuvo los votos de 37 vecinos y ante la intensificación de los acosos que siguió sufriendo, decide marcharse a vivir a Nájera, capital de la comarca y una población a dos kilómetros de distancia de Tricio.

El 18 de julio estalla la Guerra y ante la gravedad de la situación y sus posibles consecuencias contra los miembros de la familia, Ildefonso y sus tres hijos mayores (Luis, Doroteo y Feliciano) deciden un día después refugiarse entre los campos próximos. Su hijo Jesús, con 22 años de edad entonces, consigue huir por Álava hacia la zona republicana para alistarse en el Ejército Vasco. En abril del año siguiente de 1937, adscrito a una Brigada vasca de las Juventudes Socialistas Unificadas, moría en las laderas del monte Gorbea.

Por su parte, Ildefonso, el hijo más pequeño al que llamaban Fonsito, tenía 15 años y decidió esconderse, como muchas otras personas, en el Castillo de Nájera. Junto a cuatro compañeros, Fonsito piensa llegar caminando a Madrid, pero los temores a las guardias armadas les hacen retroceder. Al día siguiente, en las cercanías del pueblo de Camprovín, una población a siete kilómetros de distancia a Nájera, el hijo menor se reencuentra con su padre y los hermanos que le siguieron. Sus cuatro compañeros del frustrado viaje a Madrid, no tardaron en ser apresados y ejecutados. Una semana después de la fuga de Ildefonso y sus hijos, las secciones franquistas organizan una batida para sacar a los prófugos de los montes de Camprovín; Feliciano, de 27 años de edad, queda aislado y es detenido y enviado a la prisión del frontón Beti-Jai de Logroño, donde también fueron enviadas sus hermanas Elisa y Araceli después de ser trasladadas de la cárcel de Martutene, en San Sebastián.

Durante los meses de julio, agosto y septiembre, Ildefonso y sus tres hijos permanecen escondidos en los montes de la zona, moviéndose entre las poblaciones de Castroviejo, 
Camprovín, Ledesma y Pedroso. Llega el otoño y deciden que el hermano menor baje al pueblo de Nájera para conseguir ropa con la que puedan pasar el invierno. El 2 de octubre, aprovechando la celebración del día de San Miguel, Fonsito consigue entrar en su casa sin ser reconocido. Durante los días que intenta acopiarse de ropa y alimentos, alguien de Pedroso delata a la Guardia Civil el lugar llamado El Serradero, el lugar donde se ocultan su padre y sus hermanos. Son cercados durante la noche del día 6 y al amanecer, cuando abandonaban la choza donde habían dormido, son tiroteados. Luis (35 años) y Doroteo (29) mueren allí mismo y el padre consigue escapar arrojándose, herido, por un barranco. Llega a Nájera, se encuentra con su hijo Fonsito y deciden permanecer escondidos regresando al Serradero.

Un mes después, sin alimentos que los mantengan, a comienzos de noviembre deben volver a Nájera para conseguirlos. El plan era reunirse con el hermano pastor de Augusto Arrieta ("el Negro"), quien se les había unido en el Serradero, pero después de permanecer un día en las afueras de Nájera, son vistos y a Fonsito lo detienen a las cinco de la tarde del día ocho intentando cruzar el Río Najerilla. Permaneció en la cárcel de Nájera hasta el tres de diciembre, cuando, después de hacerle pasar por Tribunal de Menores de Logroño, es internado durante más de un año en el Reformatorio.

Tres horas antes de producirse la detención de Fonsito, habían hecho prisionera a su madre Felisa, quien fue llevada al Beti-Jai, el frontón que servía de cárcel y donde se reencontró con sus hijas Elisa y Araceli. Las tres mujeres de la casa pasaron más de un año en el Beti-Jai. También allí permanecía preso su hijo Feliciano, pero este fue sacado del frontón el 14 de diciembre y fusilado en el lugar conocido como la Barranca, en la población de Lardero, cercana a la capital de Logroño. Jesús Vicente Aguirre (2008: 961), constata, como decimos, que los tres hijos mayores de Ildefonso Nalda (Luis, Doroteo y Feliciano) fueron asesinados.

Ildefonso Nalda siguió huido por el monte y un matrimonio sin hijos pudo acogerlo en su casa de Camprovín hasta que contactó con su hermano Felipe Nalda, que vivía en la población cercana de Huércanos. Felipe habilitó un pajar como pequeño refugio de Ildefonso y allí permaneció durante dos años continuos. Libres de la cárcel y del reformatorio, Fonsito, su madre y sus hermanas, fueron acogidos por una mujer en el domicilio de la Calle Caballerías 21 de Logroño, el domicilio al que llegaría desde Huércanos, oculto en el fondo de un carro, Ildefonso Nalda. Sin pisar la calle allí vivió hasta abril de 1939, cuando acaba la Guerra, pero sigue siendo perseguido por el régimen franquista y la familia decide trasladarse a San Sebastián. Debe vivir en la clandestinidad y ante el temor de ser reconocido, como muchos otros refugiados españoles, huye a Francia. El 9 de septiembre, recién comenzada la Segunda Guerra Mundial y la inmediata implicación en ella por parte de Francia, a través de una red de evasión Ildefonso pasa a territorio francés por el Pirineo navarro.

Tras la derrota republicana en España, la llegada a Francia de miles de exiliados españoles origina la creación de "campos de acogida". El campo de la localidad de Gurs, cerca de Pau, se construye con la participación del Gobierno Vasco en el exilio en la primavera de 1939. Antes de llegar a su destino final, Carlos Muntión encuentra testimonios documentales que sitúan a Ildefonso, primero en el campo de Gurs, situado cerca de la frontera española, en el Departamento de los Pirineos Atlánticos de la región francesa de Aquitania y, algo más tarde, alojado en una granja agrícola del Departamento de La Charente, en el centro-oeste de Francia, aproximadamente a 350 kilómetros al norte de Gurs.

En el Departamento de La Charente, según el texto de Sandra Checa, Ángel del Río y Ricardo Martín, Andaluces en los campos de Mauthausen (2006: 120-121) se establecieron 
numerosos refugiados españoles que habían sido trasladados allí desde la frontera misma y acogidos en distintas poblaciones. En las afueras de la ciudad de Angoulême, capital de La Charente, se instaló el campo de refugiados de Les Alliers. Hasta el comienzo de la Guerra, estos refugiados habían sido acogidos en distintas poblaciones, la mayoría de ellos en Ruelle-sur-Touvre o Cognac. El campo de Les Alliers no tuvo un régimen propiamente de internamiento, aunque sus prisioneros estaban sometidos a cierto grado de control ejercido por la Prefectura. Allí se alojó un gran número de españoles y se reagruparon numerosas familias que habían permanecido dispersas en distintos centros de acogida desde el inicio de su exilio. En muchos casos, haciendo parte de las Compañías de Trabajadores Extranjeros (C.T.E.), consiguieron trabajos en empresas y casas particulares del entorno, en el exterior del campo.

Cuando en mayo de 1940 se produjo el hundimiento de Francia y la desbandada de su ejército ante el ataque alemán, algunos españoles integrados en las C.T.E., huyendo hacia el sur, también acudieron al campo de Les Alliers, que era considerado el refugio de los españoles. Ante las opciones de solicitar el regreso a España, ingresar en el ejército francés para combatir a los alemanes, o pertenecer a las compañías militarizadas francesas que eran enviadas a trabajar al norte de Francia, o sea, entrar a formar parte de las C.T.E. donde los españoles eran empleados en fábricas industriales o en faenas agrícolas, esta última fue la posibilidad más elegida por los refugiados.

El ejército alemán ocupó la ciudad de Angoulême el 24 de junio de 1940, bajo la autoridad del gobierno colaboracionista de Vichy. Sin variaciones considerables en el régimen de Les Alliers, unas semanas después corrieron rumores en el campo sobre la pronta llegada de un tren que devolvería a los refugiados a España o los conduciría a zona libre francesa. Finalmente, sin ninguna explicación, el 20 de agosto, ese tren cargaría con 927 españoles que desde la estación de Angoulême, cuatro días después, en la mañana del 24 de agosto, llegaría a la estación austriaca de Mauthausen.

En septiembre 1940 Ramón Serrano Súñer, seis veces ministro, ocupando las carteras de Interior, Gobernación y Asuntos Exteriores de los primeros gobiernos franquistas entre 1938 y 1942, se entrevista con Hitler y, reconocido por su germanofilia, su destacada labor diplomática con el gobierno alemán culmina con el encuentro del 23 de octubre de Franco con Hitler. A partir de entonces, la Gestapo interviene llevando a cabo un registro pormenorizado de los presos españoles con la intención de despojarlos de su condición de prisioneros de guerra. Fueron catalogados como "Rotspanier" (rojos españoles) y una vez que el nuevo Estado franquista se desentendió de ellos al no reconocerles la nacionalidad española y ser considerados, por tanto, apátridas, fueron arrestados por las tropas alemanas y deportados a campos de concentración.

La mayoría de republicanos españoles que llegó al campo de Mauthausen lo hizo entre la segunda mitad de 1940 y el año de 1942. Como registra Adrián Blas Mínguez (2010: 41-42), el primer convoy que los trasladó al campo salió el 5 de agosto de 1940 del Stalag VII-A, situado en la población de Moosburg, al lado de Munich, Alemania. Antes de que saliese el mencionado "Convoy de los 927", se sucedieron las expediciones que salieron de Hohenstein (Polonia), de Ziegenheim (Departamento de Essen, Alemania) y Magdeburg (Alemania), y el día 20 sale del Stalag 184, o sea, del campo de Les Alliers, un tren (a él le seguirían muchos otros) que por primera vez carga juntos hombres, mujeres y niños con destino a un campo de exterminio. Llegan a Mauthausen el día 24 y de los 927 deportados que lleva el tren, el número de españoles matriculados de ese convoy en las oficinas del campo fueron 377, de los cuales, a lo largo de su internamiento, murieron asesinados 357.

En ese día se registraron las matrículas que van del número 3807 al 4237 y a Ildefonso Nalda le asignarían el número 4219 (Bermejo y Checa, 2006: 465). Después de cuatro 
años de persecución, Ildefonso acabaría llegando al campo de concentración nazi de Mauthausen, donde se encontraba la mina de granito de Wiener-Graben. A fines de 1939, Mauthausen estaba ya saturado de prisioneros y a unos cinco kilómetros de distancia, comienza a construirse un nuevo campo en Gusen que, con su cantera Kastenhofen, fue acabado en mayo de 1940 y más tarde se llamaría Gusen I.

A Gusen eran enviados los presos que eran considerados excedentes para la capacidad del campo central de Mauthausen ante la llegada de nuevos deportados, o quienes se encontraban en peores condiciones físicas. Ildefonso Nájera, con 65 años de edad, marcado con el triángulo azul de los "apátridas" y el segundo número de matrícula 10893 por su traslado, fue enviado a Gusen, un rectángulo de 800 metros de largo por 500 de ancho, con un gran patio a la derecha y 32 barracones pintados de negro a la izquierda. Gusen era el verdadero campo de exterminio y en su Libro de los muertos quedó grabada la siguiente inscripción: Nalda Nágera, Ildefonso. Tricio(Logroño). Muerto el 4/4/41 en Gusen (Mauthausen).

Una inscripción que funciona como un lacónico enunciado dentro del archivo original del Campo de Concentración. Los enunciados obedecen a un régimen de materialidad que pertenece al orden de la institución: "define posibilidades de reinscripción y de transcripción (pero también de umbrales y de límites) más que individualidades limitadas y perecederas" (Foucault, 1983: 173). Dentro de un sistema de relaciones que comporta el archivo de la institución, la identidad de este enunciado está sometida a un conjunto de condiciones y de límites impuestos por el conjunto de los demás enunciados (tipologías documentales) entre los que se encuentra. Sin embargo, más allá de esas relaciones internas que establecen los enunciados escritos del archivo, muchas veces ocultas, un solo registro, una sola marca individual es la que por sí misma establece, por un lado, posibilidades de relación con las marcas de otros individuos, dando lugar, por tanto, a una marca social que se inscribe en la totalidad del archivo; y posibilidades, por otro lado, de relación con el propio sujeto del que habla la marca.

El campo de utilización donde el enunciado se encuentra inserto (el archivo) conserva una identidad concreta a través de los acontecimientos singulares de las enunciaciones que produjo la administración nazi. El enunciado posee la propiedad de poder ser "repetido" con otros sujetos, de ahí que no deba ser tratado como un acontecimiento único producido en un lugar y un tiempo determinados. Es esa posibilidad de repetición lo que hace que existan los mismos modélicos enunciados en distintos lugares y distintos tiempos dando lugar a los "archivos del mal".

Pero dentro de la repetición infinita de los enunciados, manipulables en su circulación y apropiación, hay un nombre propio. El enunciado también es, como diría Foucault, una "modalidad de existencia propia" que le permite ser algo más que una serie de trazos alfabéticos o numéricos en un soporte burocrático. La escritura del nombre propio relaciona unos trazos presentes con una imagen ausente que no es la representación física de un sujeto concreto, sino la representación de una biografía posible por la sola existencia del sujeto. Encontramos huellas que siempre funcionan como precedentes de una construcción en curso, interminable.

Es posible interpretar el archivo como biografía pero no solo, como dice Leonor Arfuch (2008: 143-157), formado sobre un eje "espacio-tiempo" concreto; también sobre un eje intemporal que trae consigo el texto, la fotografía o el artefacto, como trae consigo el recuerdo o la vivencia de innumerables seres humanos en innumerables lugares. La dimensión de la experiencia articula toda narrativa y no se sujeta a un orden previo, se sitúa lejos del "hacer del archivo", que articula la acumulación de sus fondos a un devenir lógico y a unas relaciones orgánicas de la información más allá del tiempo y el espacio. 
En la biografía no se espera la "sinceridad referencial", sino el ejercicio y las estrategias de la representación, la forma plástica de la escritura en relación con ese sujeto enmascarado y ficticio que se configura mediante una experiencia intersubjetiva. El archivo, por el contrario, se afirma en lo "objetivo", la prueba testimonial, el documento. Pero la lectura del archivo también es azarosa y se abre a la multiplicidad, su "objetualidad" establece amarres fácticos que escapan, no siempre del todo, al "efecto de real". El "nombre propio" de la trama indicial del archivo tampoco está cautivo, no puede reducirse a sus huellas ni a sus imágenes, también se desdibuja entre las interioridades de los "otros", de los innumerables sujetos que con los que convive en el archivo, y se descifra y construye en cada una de sus resurrecciones.

La vida misma se rehace una y otra vez con su carga emocional y valorativa. Ningún relato es casual ni ingenuo, vienen del pasado y ordenan la vivencia de los hechos vividos y la narración de la propia vida, y ninguno de ellos puede dar cuenta de la totalidad de la vida, así como el archivo es también inabarcable y se expande, más allá de sus límites físicos, en la experiencia, en las expectativas y en la pasión de quienes los descubren; en las historias que cada personaje despliega y despierta y en las múltiples y contradictorias interpretaciones que generan.

Tanto en la experiencia del otro y hasta en la nuestra propia, como en el relato ya escrito o por escribir que potencia el archivo, hay una confrontación de subjetividades que concede valor atemporal al espacio biográfico, allí donde se halle, y actúa así, como palanca que impulsa el rebusque de lo íntimo en una experiencia totalizadora de la existencia humana:

Lo que por un momento brilla en estos lacónicos enunciados no son-como quisiera la afectación patética de una cierta historia oral- los acontecimientos biográficos de una historia personal, sino la estela luminosa de otra historia; no la memoria de una existencia oprimida, sino el mudo ardor de un ethos inmemorial; no el rostro de un sujeto, sino la desconexión entre el viviente y el hablante que señala su puesto vacío. Puesto que aquí hay una vida que subsiste solo en la infamia en que se ha desenvuelto y un nombre que vive únicamente en el oprobio que le ha cubierto, algo en este oprobio da testimonio de ellos más allá de cualquier biografía (Agamben, 2005: 150).

La experiencia de Primo Levi en el Lager de Monowitz, cerca de Auschwitz, en la Alta Silesia, no es la experiencia, efectivamente, de un concreto sujeto, sino la experiencia del ser humano que llega a tocar fondo: "nos damos cuenta de que nuestra lengua no tiene palabras para expresar esta ofensa, la destrucción de un hombre [...] Más bajo no puede llegarse: una condición humana más miserable no existe, y no puede imaginarse [...] Si hablamos no nos escucharán, y si nos escuchasen no nos entenderían. Nos quitarán hasta el nombre y si queremos conservarlo deberemos encontrar en nosotros la fuerza de obrar de tal manera que, detrás del nombre, algo nuestro, algo de lo que hemos sido, permanezca" (Levi, 1995 [1958]: 28).

La experiencia impide el pensamiento, "es como estar ya muertos", dice Levi, y es cuando en realidad, en esta situación de muerte, se descubre el significado de un nombre propio y el significado de los objetos que hacen parte de una cotidianeidad vivida como umbral inmediato a la muerte: "pensad cuánto valor, cuánto significado se encierra aun en las más pequeñas de nuestras costumbres cotidianas, en los cien objetos nuestros que el más humilde mendigo posee: un pañuelo, una carta vieja, la foto de una persona querida" (Levi, 1995 [1958]: 28). Los nombres del Totenbuch, así como los objetos que conserva el Archiv der KZ-Gedenkstätte Mauthausen, son parte de alguien y algo real que todavía existe. Fueron, son y serán, al mismo tiempo, de su vida y su muerte; un nombre y un objeto como miembros de su propio cuerpo que hace impensable que se vean privados de ellos porque fueron, son y serán nombres 
y objetos que custodian y suscitan sus recuerdos, el recuerdo del propio muerto en vida, o de la propia "vida en muerte".

\section{El archivo: ¿un discurso sin autor?}

Foucault parte del potencial analítico del archivo en tanto posibilita una variedad de análisis enunciativos. Lo relevante para él no es su génesis, la razón de su nacimiento, sino caracterizar y fundamentar los enunciados que puedan originarse a partir de él, independientemente de su propia enunciación, de la propia existencia de los documentos. Para Giorgio Agamben (2005: 147) desde el momento en que los enunciados son el centro de la investigación en Foucault, "el sujeto queda liberado de cualquier implicación sustancial y pasa a ser una pura función o una pura posición". El sujeto se convierte en un lugar vacío que cualquier individuo puede ocupar, pues "el sujeto enunciante hace existir fuera de él un objeto que pertenece a un dominio ya definido, cuyas leyes de posibilidad han sido articuladas ya y cuyas características son anteriores a la enunciación que lo crea". Si una proposición, frase o un texto pueden ser llamados "enunciados" no es porque haya habido un efectivo productor de los mismos, es más bien porque en ellos puede establecerse la posición del sujeto. Describir los "enunciados" no es analizar las relaciones entre el autor y lo que ha dicho, sino "determinar cuál es la posición que puede y debe ocupar todo individuo para ser su sujeto" (Foucault, 1983: 158-160).

Foucault piensa en que se puede imaginar una cultura en que los discursos circularan y se apropiaran en el anonimato, sin que apareciera la función de autor. Desde esta consideración, para Agamben, Foucault no se interroga sobre las implicaciones éticas de su teoría de los enunciados. Su compromiso por "borrar y despsicologizar" al autor, por descartar el falso problema de "quién habla" con una especie de "ética inmanente de la escritura", ha impedido formular una inevitable pregunta:

¿Qué sucede en el individuo viviente en el momento en que ocupa el "puesto vacío" del sujeto, en el punto en que, al entrar en un proceso de enunciación, descubre que [en palabras de La Arqueología del saber] "nuestra razón no es más que la diferencia de los discursos, que nuestra historia no es más que la diferencia de los tiempos, que nuestro yo no es más que la diferencia de las máscaras" (Agamben, 2005: 148-149).

Agamben intenta responder así a qué significa ser sujeto de una desubjetivación y cómo un sujeto puede dar cuenta de su propia disolución. La dificultad, dice, está implícita en el concepto mismo de una "semántica de la enunciación". Esta se sostiene sobre un "acontecimiento de lenguaje" y no sobre un "contenido de significado"; no sobre lo dicho sino sobre un "puro decir"; no sobre el "texto del enunciado" sino sobre su "tener lugar". El sujeto de la enunciación funda la posibilidad de una metasemántica de los saberes, constituye un sistema de enunciados y no puede tomarse a sí mismo como objeto, enunciarse: "no puede haber, pues, una arqueología del sujeto como hay una arqueología de los saberes" (Agamben, 2005: 149).

Estas serían premisas para pensar que el "autor" no puede desaparecer por completo y perderse en el anonimato. Más que nunca, cuando el "ethos" de los que hemos llamado, desde una categoría asociada a los modos del comportamiento humano, "archivos del mal", demuestra que sí importa quién habla, desde dónde y de quién, pues que haya una continuidad intemporal de ellos y podamos tomar sus enunciados como un modélico discurso del mal, no imposibilita atender a su voluntad creadora, esté esta asociada a una "conciencia del mal" o no. El mal como "aquello que desafía y hace 
3. Una realidad imposible que produce la impotencia de decir, de escribir lo visto, lo hecho ante unos determinados estados de ánimo, los que también convierten a Béla Zsolt en un espectador incrédulo, en un mirón “de los horrores imposibles que ocurren delante de sus ojos, y también de los acontecimientos improbables y de los sufrimientos que le esperan. No se trata de esa indiferencia casi humana desarrollada a causa del sinfín de horrores vividos. Más bien es que no llega a creerse que lo que está ocurriendo pueda ocurrir de verdad. Uno se enfrenta a variantes tan extremas e imposibles de terror -fuera de cualquier posibilidad conocida o imaginada- que se muestra incapaz de digerirlas aunque estén ocurriendo delante de sus propios ojos [...] Ahora ya

sé que no se trata de impasibilidad ni de inocencia. El ser humano se resiste, simplemente, a creer que

lo que le ocurre le está ocurriendo

de verdad, a aceptar que de verdad es igual a sí mismo. Es como la esquizofrenia, el desdoblamiento de la personalidad; y yo mismo tenía la sensación de no ser igual

a mí mismo, como probablemente ellos también, al ser arreados y metidos en los vagones, tenían la sensación de no ser ellos mismos, ni siquiera de ser sus dobles, sino más bien unas terceras personas, ajenas y desconocidas" (Zsolt, 2004: 262-263). El mismo Rudolf Höss, comandante en Auschwitz, se preguntaba por cómo podían

sobrevivir los judíos del "sonderkommando”: “¿Esperaban que un milagro los salvara, estando ya a las puertas de la muerte? ¿O se habían vuelto demasiado cobardes, demasiado inhumanos, después de

haber visto tantos horrores, para poner fin a sus días y escapar a tan atroz existencia?” (Höss, 2009: 147) añicos esa inteligibilidad que hace que el mundo sea habitable", aquello que "tiende a ser invocado cuando insistimos en explicar lo inexplicable (Bauman, 2007: 75-76).

En oposición al "archivo", que define el sistema de las relaciones entre lo no dicho y lo dicho, entre la "langue" y la "parole", entre la función enunciativa y el discurso sobre el que se proyecta, entre el fuera y el dentro del lenguaje, Agamben llama "testimonio" al "sistema de las relaciones entre el dentro y el afuera de la "langue", entre lo decible y lo no decible en toda lengua; o sea, entre una potencia de decir y su existencia, entre una posibilidad y una imposibilidad de decir". Mientras el "archivo" presupone dejar al margen al sujeto, lo decisivo en el "testimonio" es el puesto vacío del sujeto para poder entender cómo puede producirse una enunciación en el plano de la lengua o en el plano de la escritura documental, cómo puede atestiguarse como tal una posibilidad de decir o de escribir. Si en el archivo, en la relación entre lo dicho y su tener lugar, el sujeto del enunciado puede quedar liberado porque ya se había producido la toma de palabra, "la relación entre la lengua y su existencia, entre la 'langue' y el archivo, exige una subjetividad que atestigua, en la posibilidad misma de hablar, una imposibilidad de palabra". Por eso, el archivo y su escritura se presenta como "testigo" y puede hablar por aquellos que no pueden hacerlo (Agamben, 2005: 151-153).

En los campos de concentración, en las dictaduras, en los conflictos armados, el testimonio oral o el testimonio escrito personal o burocrático se convierte en una potencia que adquiere realidad mediante una impotencia de decir o creer lo que se dice o está escrito; y en una imposibilidad que cobra existencia a través de una posibilidad de hablar, de fijar por escrito un testimonio, un simple recuerdo, o hallar en el archivo la prueba de una existencia. De esa imposibilidad que constituye a la misma realidad es de la que habla Béla Zsolt en el gueto de Nagyvárad (Rumania):

La realidad se ha hecho imposible, y si el escritor quisiera reflejarla tal como es, se convertiría en un bufón que solo busca efectos gratuitos con sus exageraciones. Si yo quisiera que me creyeran, tendría que reagrupar los acontecimientos disminuyendo al mínimo su contenido real y a la vez increíble; si quisiera describir a los hombres que he conocido, tendría que falsificar mis impresiones sobre ellos y revestirlos con rasgos humanos (Zsolt, 2004: 262-263)3.

Mauthausen representa a través de su archivo la experiencia devastadora donde lo "increíble" se introdujo a la fuerza en lo real. Lo humano y lo inhumano, un "hacer vivir" o un "dejar morir", la subjetividad está potencialmente adherida al ser del archivo. Por eso es inevitable preguntarse por la categoría de "autor" en relación al concepto de "génesis documental" en tanto sin su voluntad, previa al archivo, este no existiría. Es este "autor" a quien podemos poner en relación con una conciencia creadora que tiene correspondencia con los enunciados potenciales que pueden surgir del archivo, con el puro tener lugar del lenguaje.

En relación al "autor" hay que situar al "sujeto" de los enunciados que, en lo dicho, en la escritura de los registros documentales, hay que hacer corresponder con quien aparece en ellos, bien diciéndose algo sobre él, bien realizando un determinado acto como puede ser el de la estampación de su firma. Las marcas documentales que hablan de Ildefonso Nalda Nájera aparecen fijadas en el archivo como huellas de unos sujetos en las que se adivina una experiencia vivida. El testimonio siempre es, no obstante, un acto de autor que implica, por tanto, una doble presencia: la institucionalidad que da origen al archivo, y la del sujeto representado en la confección de sus registros. Un sujeto del testimonio que aparece al mismo tiempo como una imposibilidad y una posibilidad de decir; como la representación, en la terminología 
de Primo Levi, de un "no-hombre y un hombre"; como un viviente constitutivamente escindido; como el sujeto de una desubjetivación (Agamben, 2005: 158).

"Autor" " "sujeto" quedan entonces articulados entre sí si pensamos que el archivo no solo es el sistema de potenciales enunciados formado por una voluntad de "autor", sino que es el propio enunciado de esa voluntad. El autor, en este caso, como fundador del orden que representa el surgimiento o la existencia de un archivo, a través del cual se custodia la ley, el mandato de una autoridad y los actos resultantes de ella; el archivo que legitima lo humanamente ilegitimable. El autor del archivo no puede ser considerado aquí, desde luego, como el individuo que habla o ha producido un texto escrito, sino como una entidad que tiene como principio el de la "agrupación del discurso como unidad y origen de sus significaciones, como foco de su coherencia" (Foucault, 1970: 24).

En el gueto de Kelepecz, a las diez de la mañana se presentaba el funcionario del Registro Civil para tomar nota de los nombres de los fallecidos: "Acabada de llegar al gueto con su ayudante, que era quien llevaba el libro de registros. Quería hacer su trabajo, Hay que registrar a los fallecidos en el libro, así lo determinaba la ley" (Zsolt, 2004: 79-80), como así se determinó con el Totenbuch de Mauthausen. "Se había dado una orden y yo debía ejecutarla", dice Rudof Höss en sus memorias (2009: 141). Adolf Eichmann, teniente coronel de las SS, en el juicio que se llevó a cabo contra él en 1961, en la ciudad de Jerusalén, repitió una y otra vez que él cumplía con su deber; no solo obedecía órdenes, sino también la ley. Todas las actuaciones estatales estaban respaldadas en leyes, decretos, reglamentos, cuando no en la propia palabra del Führer, considerada como fuerza de ley, algo que significaba, entre otras cosas, que si la orden emanaba directamente de Hitler no era preciso que constara por escrito (Arendt, 1999: 4, 83 y 90) 4 .

Una ley que en el comienzo, como dice Agamben, solo puede ser una orden. La orden como forma de lenguaje que no tiene origen porque la orden es el origen o está en el origen: "el poder no está definido solo por su capacidad de ser obedecido sino, antes que nada, por su capacidad para dar órdenes y mandatos, incluso si estas órdenes no son totalmente obedecidas". Un poder que no cae cuando ya no es obedecido, sino cuando cesa de dar órdenes (Agamben, 2012: 53).

Eichmann y sus abogados dieron a entender que sus "actuaciones de muerte" estuvieron motivadas por la lealtad al servicio como funcionarios que eran de una burocracia estatal. La intención de "obrar mal" estaba, pues, ausente, eso fue al menos lo que sostuvieron, pues nada malo había en el cumplimiento del deber que se hacía con la mayor profesionalización y eficiencia posible conforme a la ley. La defensa de Eichmann, no obstante, que se repite con múltiples variaciones en los innumerables casos perpetrados en la actualidad categorizados como "crímenes de estado", deja dudas de su convencimiento moral, y las palabras de Rudolf Höss, en este sentido, lo exponen con claridad: "Sabíamos que las órdenes del Führer eran incontestables sin excepción, y que los SS estaban obligados a ejecutarlas. Sin embargo, en el alma de todos se alzaban las dudas. Para transmitirles la fuerza moral que les permitiera cumplir su deber, debía mostrarme totalmente convencido de la necesidad de ejecutar tan crueles órdenes" (Höss, 2009: 148).

Pero más allá de la existencia de esa "conciencia del mal" o no, lo que nos interesa aquí es la voluntad creadora que posibilita la existencia del archivo, pues es él quien se constituye en prueba de esa ley emanada de la burocracia nazi. Son los actos emanados de la ley, y no la conciencia, los que explican la sorpresa, el desconcierto y la desesperación que sentimos cuando conocemos lo sucedido en Auschwitz o Mauthausen y no sabemos cómo digerir aquella verdad y encontrarle un lugar en el mundo en que actualmente vivimos, donde similares enunciados de muerte documentales siguen reproduciéndose.
4. Los nazis cambiaron el término militar Befehlsempfänger ("receptor de órdenes") por el de Befehlsträger ("portador de órdenes"), indicando con ello la carga de responsabilidad que se pretendía pesaba sobre los hombres de aquellos cuya función era la de ejecutar las órdenes. Eichmann, además de ser un "portador de órdenes", era, oficialmente, como todos quienes intervinieron en la Solución Final, un Geheimnisträger ("portador de secretos") (Arendt, 1999: 21). La escritura no era necesaria para poder recibir información y órdenes de los superiores, y la propia categoría de ser "portador de secretos", secretos en relación al significado etimológico del archivo (el arkheîon griego-los arcontes, los que mandan-; el archivum o el archium latino; el arca o los arcanus) lo situaba al mismo nivel funcional y privilegiado que el que poseía el propio archivo de la burocracia nazi. 
Según Höss (2009: 194), en Auschwitz se quemaban en el acto, de acuerdo a las órdenes del Reichsführer, todos los documentos susceptibles de ofrecer información sobre la cantidad de exterminados. Como jefe de la Sección D1, debía destruir todos los documentos que le llegaban. Las demás secciones hacían lo mismo. Durante las últimas semanas de guerra, la burocracia de las SS se ocupó de confeccionar falsos documentos de identidad y de destruir los documentos que constituían la prueba de seis años de sistemáticas matanzas. El departamento de Eichmann quemó sus archivos, pero no logró con ello sus propósitos, pues toda su correspondencia había sido dirigida a otras oficinas del Estado y del partido, cuyos archivos fueron a parar a manos de los aliados. "Había documentos más que suficientes, dice Arendt (1999: 133), para reconstruir la historia de la Solución Final, muchos de ellos conocidos ya a través de los juicios de Nuremberg y los que les siguieron". El mismo Höss habla de la importancia de la documentación para poder mantener los campos de concentración y controlar sus actuaciones:

Los documentos, las instrucciones y la correspondencia de todos los campos que tenía archivados en mi oficina me permitían seguir su evolución desde el momento en que Eicke había llegado a inspector, y hacerme una idea exacta de la situación. Muchos campos de concentración no los conocía personalmente. En mi oficina se registraba toda la correspondencia del cuerpo de Inspectores de Campos de Concentración (Höss, 2009: 153).

Como instrumento de control, de memoria administrativa, que da cuenta de las relaciones de dependencia existentes entre la institución, que lo crea y lo custodia, y sus sujetos sometidos a ella, el archivo constituye un recurso de poder al servicio de las clases gobernantes y cumple, según Derrida, con uno de sus principios: "el principio según la ley, allí donde los hombres y los dioses mandan, allí donde se ejerce la autoridad, el orden social" (Derrida, 1997: 9).

Las acciones, derivadas de las propias funciones legislativas, administrativas, o jurídicas, llevadas a cabo por el cuadro organizativo de la burocracia nazi en sus distintas instituciones y la perpetuación de las mismas en su seno, traen consigo su obligada escrituración, asistiendo así a lo que se ha llamado "inevitabilidad de archivo" o "involuntariedad de la producción documental", inherente a una organización administrativa dada. No obstante, la insistencia en esta verdad (el carácter involuntario de la génesis documental), inobjetable, "ha dejado en penumbra la voluntariedad del archivo y, con ella, su historicidad. Da la sensación de que los archivos han nacido por generación espontánea y que en su creación y desarrollo ninguna voluntad ha existido. Nada más lejos de la realidad. Los archivos no son inocentes" (Rodríguez de Diego, 2000: 189). El "quién", el "autor", en estos casos es lo relevante, porque juega un papel institucional empapado de violencia, literal o simbólica.

\section{Hacia un relato del "nunca más”}

Durante el año 2005, en Guatemala, una explosión descubre el archivo que la policía nacional había mantenido en secreto desde los años cuarenta del siglo XX. En él se encuentran las fichas de más de dos cientos mil guatemaltecos espiados, torturados y asesinados por sus creencias políticas. El archivo pone de manifiesto no sólo la confirmación de que tras todos estos asesinatos se encontraba el gobierno y los "escuadrones de la muerte" o los "ojo por ojo" (grupos paramilitares de extrema derecha), sino también la trama colaboracionista que posibilitó llevar a cabo el golpe 
de estado de 1954. "El hombre es aquel que puede sobrevivir al hombre", nos dijo Primo Levi. El archivo también pone de manifiesto que los hombres son y seguirán siendo un peligro para su propia especie.

Los archivos que un día formaron parte del "exterminio", de la "violencia", y pudieron rescatarse, forman hoy en día o constituyen parte de los fondos documentales de los llamados generalmente "centros de la memoria histórica" y en ellos también importa el "quién". Qué se registra en el archivo, qué se deja afuera, qué se prohíbe ver: "a la manera del biógrafo, quien construye un archivo para salvaguardar la memoria (para una posteridad) lo hace a menudo en ese movimiento especular, de admiración e identificación, en que un yo se desdobla en otro sin alinear por ello su propia voz" (Arfuch, 2008: 146).

La "aparición con vida" de fotografías, entrevistas, relatos, objetos, de las madres de mayo en la Argentina representa hoy la "restitución de las genealogías" y el descubrimiento de la "violencia del archivo": listas ocultas de desaparecidos, documentos textuales, pruebas, identificaciones, rastros biográficos que finalmente afloran hacia la construcción de un relato del Nunca Más (1984). Esta superviviencia de un régimen de materialidad de las marcas testimoniales es quizá, nos dice Arfuch (2008: 82), "la contracara más rotunda de la desaparición, así como las huellas de los campos de exterminio nazis siguen apareciendo, a más de medio siglo del fin de la guerra, contemporáneas del actual proceso (discursivo, teórico, político) de su simbolización".

La acumulación irregular que consigue la memoria a base de multitud de escenas y momentos, con su correlato obligado de olvidos, silencios, represiones, tiene su correspondencia en el archivo, donde los rostros son frecuentemente fragmentarios y solo significan en relación con la totalidad de la continuidad discursiva de la que hablamos, inalcanzable en las dimensiones espaciales y temporales del archivo, cuya narrativa se caracteriza por su tensión hacia el futuro, por su deseo de presencia y conservación.

Los cuerpos de la vida se han perdido difuminados entre el pasado y el futuro. Pero el archivo sigue caminando; sus fantasmas también, así como el documento en su origen cumplía su función, deben dirigirse al cumplimiento de una función reparadora. El interés de los archivos de la seguridad del Estado de los desaparecidos regímenes represivos queda reflejado en el estudio elaborado por un grupo de trabajo del Consejo Internacional de Archivos en los años 1995 y 1996. Este informe abarca el período de 1974 a 1994 y analiza la situación de los archivos de la represión en países tan diferentes, pero con el componente común de haber sufrido durante largo tiempo la opresión de un estado totalitario de derechas o izquierdas, como España, Grecia, Portugal, países de América Latina (Argentina, Paraguay, Chile, Brasil), Zimbabwe, Suráfrica y los países de la Europa central y del este. El informe reafirma el interés de su conservación, no solo para reconstruir un pasado reciente sino, sobre todo, como el Archiv der KZ-Gedenkstätte Mauthausen viene haciendo, para poner en funcionamiento el ejercicio de los derechos democráticos, entre otros, amnistía para los delitos de opinión o reparación a las víctimas de la represión o sus familias.

La desaparición de los documentos, muchas veces impide avanzar en la búsqueda de responsabilidades políticas y en la clarificación de los crímenes de Estado. Este mismo informe describe, en este sentido, los casos de Grecia, de la Dina con el régimen del general Pinochet y el de Suráfrica, donde desaparecieron los documentos de su policía secreta, la Nia. La falta de testimonios documentales en ambos países ha hecho necesaria una reconstrucción de la represión a partir de testimonios personales. La llamada Comisión para la Verdad y la Reconciliación fue en Chile la encargada de esta reconstrucción. Los archivos de la Stasi alemana, por el contrario, se conservaron 
casi en su totalidad y han permitido la depuración de responsabilidades (Alberch Fugueras y Cruz Mundet, 1999: 163-164)

El archivista, como el autor de una biografía o una autobiografía, debe construir una puesta en marcha y unas categorías clasificatorias que concedan orden a la memoria escrita como una narración que solo adquiere sentido en el conjunto de un sistema de relaciones. La claridad de saber sobre un hecho, una impresión, un recuerdo, como saber de un documento aislado o un conjunto de documentos que ya de por sí mantienen una específica relación en el expediente que forman, depende de la trama que el archivista, como el narrador, debe construir a base de una exposición conceptual de sus contenidos.

El archivo y la biografía son recurrentes en el mundo contemporáneo, archivos secretos que se descubren o aparecen a la luz pública, por prescripción de plazos legales, por decisión política o por lógica mediática, como los de la Stasi de la Alemania del Este o los de la Dirección de Investigaciones de la Policía de la Provincia de Buenos Aires (DIPBA), en la Argentina; o los de Colombia en el Centro de la Memoria Histórica (Bogotá), archivos del mal, así llamados por sus orígenes creadores que, bajo unas funciones similares a las del museo o del memorial, sea el Archiv der KZ-Gedenkstätte Mauthausen del que hemos hablado, potencian la posibilidad de la reconstrucción biográfica, con relatos, registros institucionales y artefactos diversos.

El proyecto del KZ Gedenkstätte Mauthausen (Memorial del campo de concentración de Mauthausen) sobre breves reconstrucciones de vida, donde se sitúa la de Ildefonso Nalda Nájera, se enmarca dentro de la proliferación actual de lo que se está denominando el "espacio biográfico", que constituye un síntoma de la época para la confrontación entre actores (estados, organismos, grupos, víctimas, victimarios) y entre opinión pública. Hay una diversidad de registros donde se traza una cartografía de la rememoración y la conmemoración (oficial, comunal) en efemérides o en monumentos, museos, memoriales, que suponen una mayor visibilidad pública, en ocasiones con hallazgos de relevantes documentos o aperturas de archivos secretos. La memoria, como lo demuestra la polémica que ha suscitado en el año 2019 el nombramiento como director del Centro Nacional de la Memoria Histórica colombiano a Rubén Darío Acevedo Carmona, quien niega la existencia del "conflicto colombiano", es esencialmente confrontativa.

Por ello se imponen las preguntas del qué, quién/es y para qué se recuerda. En la historia de una vida, están quienes testimonian dando fe de su experiencia de "haber vivido" y quienes se interrogan sobre lo sucedido desde su posteridad. Parece haber una necesidad natural por sacar a la luz lo sucedido con su correlato material (fotografías, objetos, marcas de concretos acontecimientos) y la vivencia de las víctimas se constituye en un espacio biográfico que ha podido luego ser recreado por una variedad de géneros discursivos: biografía, autobiografía, testimonios, memorias, correspondencias, relatos de vida, entrevistas, diarios, anecdotarios, conversaciones, confesiones, historias.

Objetos simples como ese cepillo de dientes o esa cantimplora metálica que un día funcionaron en el Campo de Concentración de Mauthausen, objetos cotidianos que formaron parte de una experiencia personal, que sin embargo muestran un fuerte poder evocador, emotivo y reflexivo. Operan como recordatorios que ponen en juego la dimensión activa, cognitiva de la memoria y no deben interpretarse como un recuerdo ocasional. El "hacer presente lo ausente" no es para revivir fantasmas traídos del pasado, debe actuar como una presencia instructiva para el porvenir. 


\section{Referencias Bibliográficas}

》 Agamben, Giorgio. 2005. Lo que queda de Auschwitz (El archivo y el testigo. Homo Sacer III). Valencia: Pre-textos.

"Agamben, Giorgio. 2012. Teología y lenguaje. Del poder de Dios al juego de los niños [¿Qué es una orden?]. Buenos Aires: Las Cuarenta.

" Aguirre, Jesús Vicente. 2008. Aquí nunca pasó nada. La Rioja, 1936. Logroño: Editorial Ochoa.

»Alberch Fugueras, Ramón. 2008. Archivos y derechos humanos. Gijón: Trea.

» Alberch Fugueras, Ramón y José Ramón Cruz Mundet. 1999. ¡Archívese! Los documentos del poder. El poder de los documentos. Madrid: Alianza Editorial.

»Arendt, Hannah. 1999. [1963]. Eichmann en Jerusalén. Un estudio sobre la banalidad del mal. Barcelona: Editorial Lumen.

»Arfuch, Leonor. 2008. Crítica cultural entre política y poética. Buenos Aires: FCE.

»Bauman, Zygmunt. 2007. Miedo líquido. La sociedad contemporánea y sus temores. Barcelona: Paidós.

" Bermejo, Benito y Sandra Checa. 2006. Libro Memorial: españoles deportados a los campos nazis, 1940-1945. Madrid: Ministerio de cultura.

»Checa, Sandra; Ángel del Río y Ricardo Martín. 2006. Andaluces en los campos de Mauthausen. Sevilla: Centro de Estudios Andaluces/Consejería de la Presidencia de la Junta de Andalucía.

»Derrida, Jacques. 1997. Mal de archivo. Una impresión freudiana. Madrid: Trotta.

» Farge, Arlette. 1991. La atracción del archivo. Valencia: Alfons el Magnànim.

» Farge, Arlette. 1994. La vida frágil: violencia, poderes y solidaridades en el París del siglo XVIII. México DF: Hachette.

»Foucault, Michel. 1970. El orden del discurso. Barcelona: Tusquets.

» Foucault, Michel. 1983 [1969]. La arqueología del saber. México DF: Siglo XXI editores.

" Höss, Rudolf. 2009. Yo, comandante de Auschwitz. Barcelona: Ediciones B.

»Levi, Primo. 1995 [1958]. Si esto es un hombre. Barcelona: Muchnik Editores.

»Memorial Book for the Dead of the Mauthausen Concentration Camp. Volume 1: Commentaries and Biographies. 2016. Andreas Kranebitter, ed. Viena: Association for Remembrance and Historical Reserch in Austrian Concentration Camp Momorials.

"Mínguez, Adrián Blas. 2010. Campo de Gusen. El cementerio de los republicanos españoles. Madrid: “Memoria Viva”, Asociación para el Estudio de la Deportación y el Exilio Español.

» Muntión Hernáez, Carlos. 2005. Nacer en Tricio. Morir en Mauthausen. Ildefonso Nalda Nájera. Tricio (La Rioja), 23/01/1876 - Mauthausen, 04/04/1941. En Piedra de rayo. Revista riojana de cultura popular. No. 16, 10-26.

"Nunca más, informe final de la Comisión Nacional sobre la Desaparición de Personas. 1984. Buenos Aires: Eudeba. 
"Parada, Alejandro E. 2012. El dédalo y su ovillo. Ensayos sobre la palpitante cultura impresa en la Argentina. Buenos Aires: Universidad de Buenos Aires. Facultad de Filosofía y Letras. Instituto de Investigaciones Bibliotecológicas.

»Rodríguez de Diego, José Luis. 200o. Significado del proyecto archivístico de Felipe II. En Alvar Ezquerra, A., coord. Imágenes históricas de Felipe II. Madrid: Centro de Estudios Cervantinos.

»Zsolt, Béla. 2004. Nueve maletas. Bogotá: Taurus. 